\title{
Application of integral pumping tests to investigate the influence of a losing stream on groundwater quality
}

\author{
S. Leschik ${ }^{1}$, A. Musolff ${ }^{1}$, R. Krieg ${ }^{1}$, M. Martienssen ${ }^{2}$, M. Bayer-Raich ${ }^{3}$, F. Reinstorf ${ }^{4}$, G. Strauch ${ }^{1}$, and M. Schirmer ${ }^{5}$ \\ ${ }^{1}$ UFZ - Helmholtz Centre for Environmental Research, Department of Hydrogeology, Permoserstrasse 15, \\ 04318 Leipzig, Germany \\ ${ }^{2}$ Brandenburg University of Technology Cottbus, Chair Biotechnology of Water Treatment, Siemens-Halske-Ring 8, \\ 03046 Cottbus, Germany \\ ${ }^{3}$ Amphos 21 Consulting S.L., Passeig de Rubi 29-31, 08197 Valldoreix, Barcelona, Spain \\ ${ }^{4}$ University of Applied Sciences Magdeburg-Stendal, Department of Water and Waste Management, Breitscheidstrasse 2, \\ 39114 Magdeburg, Germany \\ ${ }^{5}$ Eawag, Swiss Federal Institute of Aquatic Science and Technology, Department Water Resources and Drinking Water, \\ Ueberlandstrasse 133, 8600 Duebendorf, Switzerland
}

Received: 4 May 2009 - Published in Hydrol. Earth Syst. Sci. Discuss.: 12 June 2009

Revised: 28 August 2009 - Accepted: 10 September 2009 - Published: 1 October 2009

\begin{abstract}
Losing streams that are influenced by wastewater treatment plant effluents and combined sewer overflows (CSOs) can be a source of groundwater contamination. Released micropollutants such as pharmaceuticals, endocrine disrupters and other ecotoxicologically relevant substances as well as inorganic wastewater constituents can reach the groundwater, where they may deteriorate groundwater quality. This paper presents a method to quantify exfiltration mass flow rates per stream length unit $M_{\mathrm{ex}}$ of wastewater constituents from losing streams by the operation of integral pumping tests (IPTs) up- and downstream of a target section. Due to the large sampled water volume during IPTs the results are more reliable than those from conventional point sampling. We applied the method at a test site in Leipzig (Germany). Wastewater constituents $\mathrm{K}^{+}$and $\mathrm{NO}_{3}^{-}$showed $M_{\text {ex }}$ values of 1241 to 4315 and 749 to $924 \mathrm{mg} \mathrm{m}_{\text {stream }}^{-1} \mathrm{~d}^{-1}$, respectively, while $\mathrm{Cl}^{-}$(16.8 to $\left.47.3 \mathrm{~g} \mathrm{~m}_{\text {stream }}^{-1} \mathrm{~d}^{-1}\right)$ and $\mathrm{SO}_{4}^{2-}\left(20.3\right.$ to $\left.32.2 \mathrm{~g} \mathrm{~m}_{\text {stream }}^{-1} \mathrm{~d}^{-1}\right)$ revealed the highest observed $M_{\mathrm{ex}}$ values at the test site. The micropollutants caffeine and technical-nonylphenol were dominated by elimination processes in the groundwater between upstream and downstream wells. Additional concentration measurements in the stream and a connected sewer at the test site were performed to identify relevant processes that influence the concentrations at the IPT wells.
\end{abstract}

Correspondence to: S. Leschik (sebastian.leschik@ufz.de)

\section{Introduction}

Contamination of streams and groundwater by substances that originate from wastewater have been reported in many studies (Eiswirth et al., 2004; Vazquez-Sune et al., 2005; Ellis, 2006). Streams can become contaminated, for example, from wastewater treatment plant discharge containing contaminants that are not completely eliminated during the treatment process. Untreated wastewater is discharged to streams during combined sewer overflows (CSOs) where it leads to increased loadings of wastewater constituents (Mulliss et al., 1996). Mendoza et al. (2008) demonstrated that contaminated streams with alternating conditions between losing and gaining may pose a threat to groundwater quality. Micropollutants such as persistent pharmaceuticals, originating primarily from wastewater, have become emerging contaminants in surface water and groundwater (Fenz et al., 2005; Schwarzenbach et al., 2006; Schirmer et al., 2007; Schirmer and Schirmer, 2008). Various groundwater studies have focused on the occurrence of these substances during bank filtration (e.g. Heberer, 2002), but few studies exist on the transport of wastewater constituents from losing streams to the groundwater under natural conditions.

This paper aims to improve the knowledge on the influence of temporally losing streams on groundwater quality by presenting a method to estimate exfiltration mass flow rates per stream length unit $M_{\mathrm{ex}}$ of wastewater constituents from a stream during losing conditions. In this context the water flow from the stream to the groundwater is defined as exfiltration form the stream. The approach of Kalbus et al. (2007)

Published by Copernicus Publications on behalf of the European Geosciences Union. 
that uses integral pumping tests (IPTs; Bayer-Raich et al., 2004) for the estimation of mass fluxes $J$ at the streamaquifer interface of gaining streams was extended to the application to losing streams. The study was performed in 2008 at a test site in Leipzig, Germany (Strauch et al., 2008). The analysis was derived for four inorganic substances $\left(\mathrm{K}^{+}, \mathrm{Cl}^{-}\right.$, $\mathrm{NO}_{3}^{-}$and $\mathrm{SO}_{4}^{2-}$ ) as well as for the micropollutants caffeine (CAF) and technical-nonylphenol (NON). We operated IPTs up- and downstream of the investigated target section to account for heterogeneous concentration patterns in the vicinity of the stream. On the one hand, we faced varying concentrations resulting from heterogeneities in the aquifer and the fluctuating household-related input of wastewater to the stream during dry- and wet-weather conditions. Under these conditions, sampling during long-time pumping with IPTs yields more reliable average concentrations $c_{\mathrm{av}}$ than conventional point sampling in space and time. On the other hand, natural hydraulic gradients between stream and groundwater are disturbed by pumping. The dimensioning of the IPT needs to account for this by increasing the distance between the pumping well and the stream so that the capture zone of the pumping well does not reach the groundwater that is influenced by the intensified exfiltration from the stream. The mass flow increase $\Delta M$ downstream of the investigated stream yields $M_{\mathrm{ex}}$.

In order to interpret the concentrations and mass flow rate data from IPTs, processes that influence the concentration pattern in the groundwater need to be defined. We assume that the following processes (a) to (h) may occur at the test site. Exfiltration water concentrations from the stream are influenced by (a) temporally high concentrations in the stream as a result of variable wastewater treatment plant effluents and CSOs in the upper catchment of the stream, (b) retardation in the streambed, (c) degradation in the streambed and (d) exchange with storage pools in the pore water of the streambed and the stream banks that are fed during times of high water levels in the stream. Concentrations of target substances in the groundwater increase or decrease along the flow path from the upstream to the downstream wells due to (e) mixing of groundwater with exfiltration water from the stream, (f) hydrodynamic dispersion and mixing with groundwater recharge, $(\mathrm{g})$ retardation in groundwater and $(\mathrm{h})$ degradation in groundwater. Additional concentration measurements in the stream and in a connected sewer at the test site were performed to identify these processes.

\section{Materials and methods}

\subsection{Test site}

The investigated stream Bauerngraben (Fig. 1) is located in the urban area of the city of Leipzig (Germany). The small, artificial watercourse is constructed of cobbled pavement, whose joints are filled with sand. It has an average width of $1 \mathrm{~m}$ in the study area. The inflow to the Bauerngraben originates from a flood protection reservoir and is controlled by a weir. Under dry-weather conditions the Bauerngraben has a discharge of 0.01 to $0.03 \mathrm{~m}^{3} \mathrm{~s}^{-1}$. The Bauerngraben is strongly influenced by three outlet pipes for CSOs that are located in the east of the test site (only one is shown in Fig. 1). Due to the controlled inflow to the Bauerngraben, water level fluctuations in the stream are mainly an effect of CSOs. In the period from April 2006 to April 200743 CSOs were detected by water level logging in the Bauerngraben with water level fluctuations between 10 and $105 \mathrm{~cm}$. Observation wells near the Bauerngraben show variable groundwater levels that are above the streambed in winter and below it in summer. The IPTs were performed during losing conditions of the Bauerngraben.

The stratigraphy below the study area consists of Tertiary fine sands overlain by a Quaternary sand and gravel layer. The Quaternary sediments form a highly permeable aquifer with a hydraulic conductivity $K$ of $3 \times 10^{-4}$ to $4 \times 10^{-3} \mathrm{~ms}^{-1}$. Heterogeneous floodplain loams with an average thickness of $1.5 \mathrm{~m}$ cover the aquifer. Ram sounding in the streambed of the Bauerngraben indicated no floodplain loam below the investigated reach.

\subsection{Observed wastewater constituents}

The four inorganic substances $\left(\mathrm{K}^{+}, \mathrm{Cl}^{-}, \mathrm{NO}_{3}^{-}\right.$and $\left.\mathrm{SO}_{4}^{2-}\right)$ and two micropollutants (CAF and $\mathrm{NON}$ ) were chosen according to preliminary studies (Musolff et al., 2007; Reinstorf et al., 2008) in which these substances had already been used as wastewater indicators. Regarding possible sources of the chosen wastewater constituents, $\mathrm{K}^{+}$originates from laundry discharge (Wolf et al., 2007). Large amounts of $\mathrm{Cl}^{-}$ are washed from roads during the winter period when road salting occurs (Mayer et al., 1999), but other sources are also known (e.g. dishwashers). Nitrification of $\mathrm{NH}_{4}^{+}$, which can originate from urine, is a common source of $\mathrm{NO}_{3}^{-}$. Industrial wastewater represents a source of $\mathrm{SO}_{4}^{2-}$ (Barrett et al., 1999). CAF is a constituent of different beverages such as coffee or tea and of numerous food products (Buerge et al., 2003). Technical-nonylphenol (NON) is used for the production of non-ionic tensides, thus it originates mainly from industrial wastewater and laundry (Bradley et al., 2008).

\subsection{IPT method background}

Average concentrations $c_{\mathrm{av}}$ and mass flow rates $M_{\mathrm{CP}}$ along control planes (CP) in an aquifer can be reliably estimated by the IPT method (Bayer-Raich et al., 2004). The CPs are oriented perpendicular to the natural groundwater flow direction and contain one or more pumping wells. Long-time pumping (several days) of the wells and simultaneous sampling gives more reliable information about $c_{\mathrm{av}}$ and $M_{\mathrm{CP}}$ at the predefined $\mathrm{CP}$ than conventional point sampling, because the sampled volume is larger and small-scale plumes cannot 


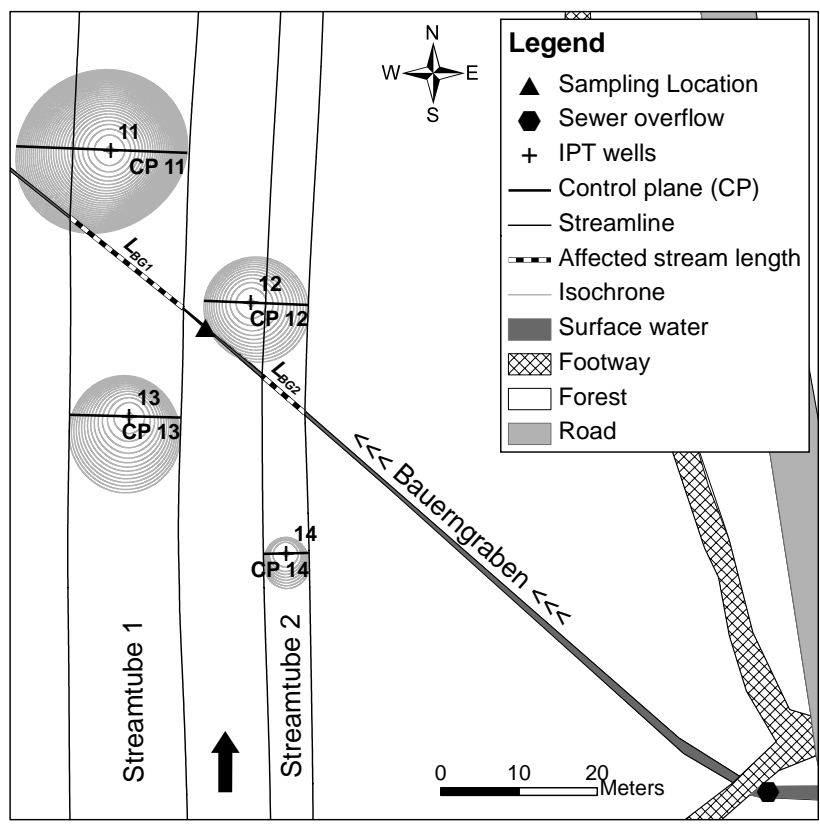

Fig. 1. Test site showing the temporally losing stream Bauerngraben, IPT wells and isochrones at sampling times. Streamlines define streamtube 1 (wells 11 and 13) and streamtube 2 (wells 12 and 14). The mean groundwater flow direction is indicated by the black arrow. Isochrones are for the $4 \mathrm{~h}$ sampling interval.

be missed. The code CSTREAM (Bayer-Raich, 2004) can be used to estimate $c_{\mathrm{av}}$ and $M_{\mathrm{CP}}$ by performing a weighted average with the values from the obtained concentrationtime series. The weights base on spatial distances between isochrones that were calculated by a particle tracking tool (Modpath) in combination with a one-layer Modflow model. The resulting isochrones define the boundary of the capture zone for the respective sample at this time. Successful operations of IPTs are reported in Bockelmann et al. (2003), Bayer-Raich et al. (2006) and Kalbus et al. (2007).

\subsection{IPT design at the study area}

Four IPT wells (11, 12, 13 and 14), two upstream and two downstream of the Bauerngraben, were drilled in the study area (Fig. 1) and screened along the Quaternary aquifer with HDPE-tubes. Over a period of five days (28 May to 2 June 2008), wells 11,12 and 13 were operated with a pumping rate of $1 \mathrm{Ls}^{-1}$. Due to operational problems at well 14, pumping was reduced to $0.5 \mathrm{Ls}^{-1}$ and stopped already after $32 \mathrm{~h}$. The standard parameters of $\mathrm{pH}$, electrical conductivity, oxygen content and temperature were measured in the pumping wells during the entire pumping period. The drawdown in 12 observation wells was measured at least every $2 \mathrm{~h}$ (with shorter intervals directly after the beginning of pumping) using a water level logging device in the pumping wells.

\subsection{IPT evaluation}

A groundwater model of the Quaternary aquifer was built with the software model Processing Modflow. The homogeneous, semi-confined model covers an extent of $200 \times 300 \mathrm{~m}$ with an average aquifer thickness of $5.8 \mathrm{~m}$ at the wells. In the model grid cell sizes vary from $1 \mathrm{~m}$ at model boundaries to $0.25 \mathrm{~m}$ in the pumping area. Fixed head cells were implemented at the north and south boundaries of the model domain. The parameters of hydraulic conductivity $K=4.5 \times 10^{-4} \mathrm{~ms}^{-1}$, gradient $i=4.1 \times 10^{-3}$ and effective porosity $n_{\mathrm{e}}=0.2$ were estimated from various field measurements and set for water flow calculations. Water levels in groundwater on 25 May before the start of pumping were measured to be $20 \mathrm{~cm}$ below the streambed of the Bauerngraben, indicating that water was flowing from the Bauerngraben to the groundwater. For that reason it was assumed that pumping-induced drawdown would not increase the leakage from the Bauerngraben. Therefore, the leakage was implemented as a constant discharge rate per stream length unit $Q_{\mathrm{ex}}$. Best fitting of observed to simulated water levels at the observation wells was obtained for a $Q_{\text {ex }}$ of $85 \mathrm{~L} \mathrm{~m}_{\text {stream }}^{-1} \mathrm{~d}^{-1}$. The average deviation between the simulated and observed water levels was $3 \mathrm{~cm}$. Isochrones for the respective sampling schedule and streamlines (Fig. 1) were obtained by the particle tracking code Modpath. In order to get a complete overlapping of the upstream CPs $(13,14)$ by the downstream CPs $(11,12)$, the considered volume was reduced by neglecting samples of wells 12 and 13 at the end of the pumping period (Fig. 1). Streamtubes 1 and 2 are defined by streamlines from the groundwater model before pumping and by the CP extents of wells 13 and 14 that determine the width $b$. These streamtubes were used for mass balance calculations between the up- and downstream wells of the Bauerngraben. The estimation of $c_{\mathrm{av}}$ for the different $\mathrm{CPs}$ was derived with the code CSTREAM in combination with the groundwater model. Corresponding $M_{\mathrm{CP}}$ values were obtained by multiplying $c_{\mathrm{av}}$ with the respective water flow $Q_{\mathrm{CP}}$. Thus $M_{\mathrm{CP}}$ specifies only the part of the CP at wells 11 and 12 that is located in the respective streamtube. Values of $Q_{\text {CP }}$ were derived from the groundwater model. Differences of $M_{\mathrm{CP}}$ values between upstream and downstream wells depend on concentrations differences $\Delta c$ and on different water flows $Q_{\mathrm{CP}}$. For the comparison of the two streamtubes the mass fluxes $J_{\mathrm{CP}}$ at each $\mathrm{CP}$ were included. Values of $M_{\mathrm{ex}}$ were calculated by

$M_{\mathrm{ex}}=\frac{M_{\mathrm{CP} Y}-M_{\mathrm{CPX}}}{L_{\mathrm{BG}}}$,

where $M_{\mathrm{CP} X}$ and $M_{\mathrm{CP} Y}$ are the mass flow rates up- and downstream of the Bauerngraben and $L_{\mathrm{BG}}$ is the affected stream length, which is marked in Fig. 1. The estimation of $M_{\mathrm{ex}}$ was only possible for substances that show a downstream mass flow rate increase (positive $\Delta M_{\mathrm{CP}}$ ). 


\subsection{Sampling in groundwater, surface water and wastewater}

Groundwater samples were taken during the pumping period 28 May to 2 June 2008 from a tap at the IPT wells following a predefined schedule: samples for inorganic analyses every $4 \mathrm{~h}$ and samples for organic analyses every $8 \mathrm{~h}$. After $56 \mathrm{~h}$ the sampling frequency for organic substances was reduced to $16 \mathrm{~h}$. Surface water sampling was completed with an automatic sampling device that pumped surface water from the Bauerngraben (location in Fig. 1) to storage bottles every 5 minutes during the period 17 May to 2 June 2008. A reduction of the sample number from the surface water was achieved by mixing all $5 \mathrm{~min}$ samples from one day in one bottle. The obtained 17 mix-samples were analyzed for the target substances. In a former study (Leschik et al., 2009), grab samples of wastewater were taken from a sewer that was connected to the overflow pipe which discharges into the Bauerngraben (Fig. 1). These samples were picked during a $24 \mathrm{~h}$ period in February 2008 at an interval of $2 \mathrm{~h}$ for inorganic analysis and $8 \mathrm{~h}$ for organic analysis to quantify daily concentration variations of target substances.

\subsection{Sample preparation and chemical analysis}

Samples were stored cooled in $60 \mathrm{~mL}$ HDPE bottles for inorganic analysis and $1 \mathrm{~L}$ amber glass bottles for organic analysis. Ion chromatography was applied to analyze $\mathrm{K}^{+}, \mathrm{Cl}^{-}$and $\mathrm{SO}_{4}^{2-}$ with limits of detection (LOD) of $1,0.1$ and $1 \mathrm{mg} \mathrm{L}^{-1}$, respectively. $\mathrm{NO}_{3}^{-}$was analyzed by the photometric salicylic acid method (LOD of $0.5 \mathrm{mg} \mathrm{L}^{-1}$ ).

The sample preparation for micropollutant analysis was derived by solid phase extraction (SPE) to enrich the target compounds from the water samples. Before they were concentrated, samples ( $1 \mathrm{~L}, \mathrm{pH}$ at about 7) were filtered through a glass fiber filter and spiked with the internal standards (100 ng 4-n-nonylphenol). The filtrates were adjusted to $\mathrm{pH} 2$ and concentrated by SPE using a sorbent mixture (C18 and Lichrolut $\left.{ }^{\circledR} \mathrm{EN}\right)$ preconditioned with methanol and water. After application of the water sample, the sorbent was dried under inert gas and finally eluted with methanol and acetone. After evaporation of the solvent to a final volume of $300 \mu \mathrm{L}$ a cleanup with silica gel was accomplished using a mixture of acetone and hexane. Evaporation of the solvent to a volume of $200 \mu \mathrm{L}$ gives the sample for GC-MS analysis.

The GC-MS analyses of the micropollutants were performed using a Varian GC/MS (CP 3800, MS 1200) equipped with a temperature-programmable injection port. The gas chromatographic separation was carried out on a $60 \mathrm{~m}$ long Zebron ZB1 capillary column of $0.25 \mathrm{~mm}$ internal diameter and $0.25 \mu \mathrm{m}$ film thickness (Phenomenex). The samples ( 5 to $10 \mu \mathrm{L}$ each) were injected at $50^{\circ} \mathrm{C}$ by large volume injection. The GC oven program started at an initial temperature of $50^{\circ} \mathrm{C}$. Helium was used as the carrier gas in a constant flow mode at $1 \mathrm{~mL} \mathrm{~min}^{-1}$. The mass spectrometer operated at positive electron impact ionization mode with 70 $\mathrm{eV}$. The GC-MS interface temperature was set at $270^{\circ} \mathrm{C}$ and the source temperature at $200^{\circ} \mathrm{C}$. A solvent delay of $8 \mathrm{~min}$ was used to fade out the solvent signal. The investigations utilized selected ion monitoring (SIM) for sensitive detection of the target analytes (target ions caffeine -194, 149, 109; nonylphenols -220, 149, 107). All sample extracts were twice analyzed and after every fourth analysis blank analysis was carried out to check carryover and memories of previous analyses. The standard mixture was measured repeatedly within every sample series.

\section{Results and discussion}

\subsection{Concentrations of wastewater constituents in groundwater}

Concentration-time series and standard parameters of the IPT wells were evaluated in order to derive concentration differences $\Delta c$ between the wells, especially downstream of the Bauerngraben. These $\Delta c$ identify how the inflow from the Bauerngraben influences the groundwater quality at the test site.

The measured $\mathrm{pH}$ of 6.2 to 6.4 , an oxygen content of 0 to $1 \mathrm{mg} \mathrm{L}^{-1}$ and temperatures of 9 to $10^{\circ} \mathrm{C}$ obtained from the wells during the pumping period did not indicate a large difference between the pumped water from different locations, whereas the electrical conductivity in well 12 of 1360 to $1450 \mu \mathrm{Scm}^{-1}$ in comparison to the other wells (1260 to $1370 \mu \mathrm{Scm}^{-1}$ ) points to a difference in the ion composition of the groundwater.

The influence of the Bauerngraben can be identified by higher concentrations of $\mathrm{Cl}^{-}$and lower concentrations of $\mathrm{SO}_{4}^{2-}$ at the downstream wells 11 and 12 (Fig. 2). The concentration comparison between up- and downstream wells has to focus mainly on average concentrations that include all observed concentration values at one well. The comparison of single concentration values between two wells for a specific time (e.g. after $8 \mathrm{~h}$ ) is not useful because shortly after start of pumping the control plane extents of up- and downstream wells (see isochrones in Fig. 1) do not or only in small parts overlap. Hence for $\mathrm{K}^{+}$higher concentrations can be identified at downstream well 12 whereas wells 11 and 13 show $\mathrm{K}^{+}$concentrations in a similar range. $\mathrm{NO}_{3}^{-}$shows a similar concentration pattern between upstream and downstream wells with mostly increased concentrations downstream of the Bauerngraben in both streamtubes, but concentrations in streamtube 2 are generally higher than in streamtube 1 . This is caused by heterogeneous inflows of wastewater constituents to the groundwater upstream of the test site where parts of the urban area of Leipzig are located. The comparison of the obtained ion concentrations at the test site with other studies of urban groundwater (e.g. Choi et al., 2005) reveals high ion concentrations in the urban aquifer of 

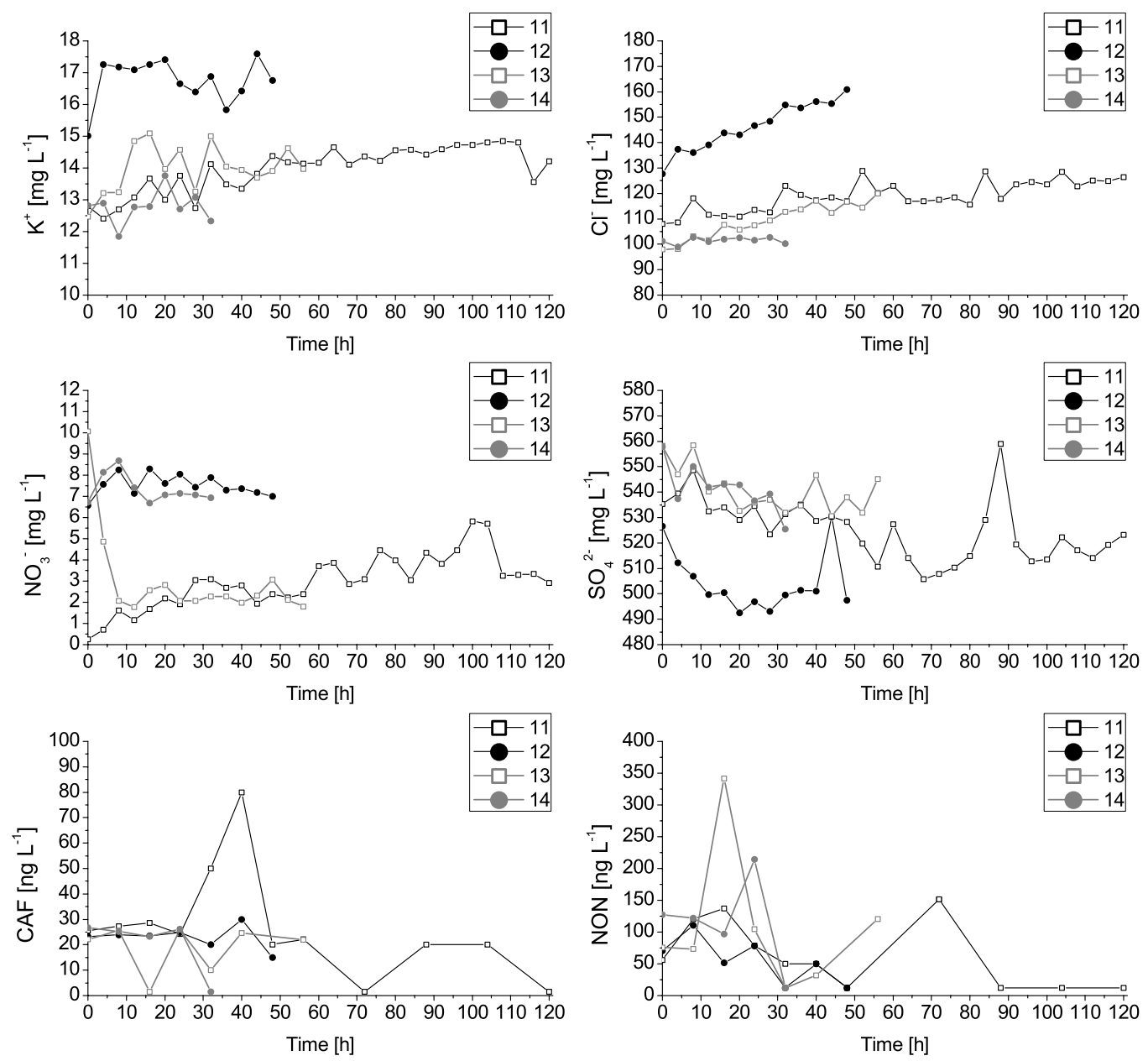

Fig. 2. Concentration-time series for the estimation of $M_{\mathrm{CP}}$ with the CSTREAM code. Concentrations are given for inorganic wastewater constituents as well as for caffeine (CAF) and technical-nonylphenol (NON) at the four IPT wells 11, 12, 13 and 14. Concentrations below the LOD were set to half of the LOD.

Leipzig. This indicates a strong influence of the urban area of Leipzig on the groundwater composition, but also shows that additional sources of the investigated ions (unassociated with wastewater) exist upstream of the test site. Examples of these additional sources are abandoned metalworking and chemical industries that act as point sources of the investigated substances.

A higher variability in the concentration-time series for micropollutants in comparison to inorganic substances points to a more heterogeneous concentration pattern of micropollutants in the groundwater. Due to these high variations, the identification of micropollutant $\Delta c$ values between IPT wells from concentration-time series alone is not feasible. A more reliable comparison of the average concentration $c_{\mathrm{av}}$ at the IPT wells was conducted using $M_{\mathrm{CP}}$ and $J_{\mathrm{CP}}$ values from the CSTREAM code calculations.

\subsection{Mass flow rates of wastewater constituents}

Values of $M_{\mathrm{CP}}$ from IPTs depend on the estimated water flow through the CP. Since the CP length $L_{\mathrm{CP}}$ is defined by the isochrone shape, in this section we will briefly discuss these isochrones. The isochrone shape in Fig. 1 is influenced by pumping-induced interaction between wells and natural groundwater flow, which shifts the isochrones upstream. At the end of the pumping period, the capture zones of wells 11 and 12 reach areas of the aquifer that are upstream of the Bauerngraben, thus measured concentrations at this time are mixed between up- and downstream groundwater. As the concentration-time series did not show a significant change in the water composition at this time, and the pumped upstream volume is small compared to the pumped downstream volume, this was neglected for the evaluation of the IPTs.

The obtained $M_{\mathrm{CP}}$ and $J_{\mathrm{CP}}$ (Table 1) mainly confirm the differences in the groundwater composition between the IPT 
Table 1. Mass flow rates $M_{\mathrm{CP}}$, mass fluxes $J_{\mathrm{CP}}$ of the different control planes and exfiltration mass flow rates $M_{\mathrm{ex}}$ for two streamtubes. The water flow $Q_{\mathrm{CP}}$ through the respective control planes, the width of the streamtubes $b_{1}$ and $b_{2}$ as well as the affected stream length $L_{\mathrm{BG} 1}$ and $L_{\mathrm{BG} 2}$ of the two streamtubes are given.

\begin{tabular}{|c|c|c|c|c|c|c|c|c|c|c|c|c|}
\hline & \multicolumn{6}{|c|}{ Streamtube 1} & \multirow{2}{*}{\multicolumn{6}{|c|}{$\begin{array}{c}\text { Streamtube } 2 \\
b_{2}=5.84 \mathrm{~m} L_{\mathrm{BG} 2}=7.23 \mathrm{~m}\end{array}$}} \\
\hline & \multicolumn{6}{|c|}{$b_{1}=14.25 \mathrm{~m} \quad L_{\mathrm{BG} 1}=18.55 \mathrm{~m}$} & & & & & & \\
\hline & \multirow{3}{*}{\multicolumn{2}{|c|}{$\begin{array}{c}\text { Upstream } \\
\text { Well } \\
Q_{\mathrm{CP} 13}= \\
13.72 \mathrm{~m}^{3} \mathrm{~d}^{-1}\end{array}$}} & \multirow{3}{*}{\multicolumn{2}{|c|}{$\begin{array}{c}\text { Downstream } \\
\text { Well } \\
Q_{\mathrm{CP} 11}= \\
15.30 \mathrm{~m}^{3} \mathrm{~d}^{-1}\end{array}$}} & \multirow[b]{4}{*}{$\begin{array}{r}\Delta M_{\mathrm{CP} 1} \\
{[\%]}\end{array}$} & \multirow[b]{4}{*}{$\begin{array}{c}M_{\mathrm{ex} 1} \\
{\left[\frac{\mathrm{mg}}{\mathrm{md}}\right]}\end{array}$} & \multirow{3}{*}{\multicolumn{2}{|c|}{$\begin{array}{c}\text { Upstream } \\
\text { Well } \\
Q_{\mathrm{CP} 14}= \\
5.00 \mathrm{~m}^{3} \mathrm{~d}^{-1}\end{array}$}} & \multirow{3}{*}{\multicolumn{2}{|c|}{$\begin{array}{c}\text { Downstream } \\
\text { Well } \\
Q_{\mathrm{CP} 12}= \\
5.61 \mathrm{~m}^{3} \mathrm{~d}^{-1}\end{array}$}} & \multirow[b]{4}{*}{$\begin{array}{r}\Delta M_{\mathrm{CP} 2} \\
{[\%]}\end{array}$} & \multirow[b]{4}{*}{$\begin{array}{c}M_{\mathrm{ex} 2} \\
{\left[\frac{\mathrm{mg}}{\mathrm{md}}\right]}\end{array}$} \\
\hline & & & & & & & & & & & & \\
\hline & & & & & & & & & & & & \\
\hline & $\begin{array}{r}M_{\mathrm{CP} 13} \\
{\left[\frac{\mathrm{mg}}{\mathrm{s}}\right]}\end{array}$ & $\begin{array}{l}J_{\mathrm{CP} 13} \\
{\left[\frac{\mathrm{mg}}{\mathrm{m}^{2} \mathrm{~s}}\right]}\end{array}$ & $\begin{array}{r}M_{\mathrm{CP} 11} \\
{\left[\frac{\mathrm{mg}}{\mathrm{s}}\right]}\end{array}$ & $\begin{array}{c}J_{\mathrm{CP} 11} \\
{\left[\frac{\mathrm{mg}}{\mathrm{m}^{2} \mathrm{~s}}\right]}\end{array}$ & & & $\begin{array}{r}M_{\mathrm{CP} 14} \\
{\left[\frac{\mathrm{mg}}{\mathrm{s}}\right]}\end{array}$ & $\begin{array}{l}J_{\mathrm{CP} 14} \\
{\left[\frac{\mathrm{mg}}{\mathrm{m}^{2} \mathrm{~s}}\right]}\end{array}$ & $\begin{array}{r}M_{\mathrm{CP} 12} \\
{\left[\frac{\mathrm{mg}}{\mathrm{s}}\right]}\end{array}$ & $\begin{array}{c}J_{\mathrm{CP} 12} \\
{\left[\frac{\mathrm{mg}}{\mathrm{m}^{2} \mathrm{~s}}\right]}\end{array}$ & & \\
\hline $\mathrm{K}^{+}$ & 2.24 & 0.026 & 2.50 & 0.029 & 11.9 & 1241 & 0.73 & 0.023 & 1.10 & 0.034 & 49.2 & 4315 \\
\hline $\mathrm{Cl}^{-}$ & 17.90 & 0.206 & 21.50 & 0.248 & 20.1 & 16750 & 5.85 & 0.184 & 9.81 & 0.308 & 67.6 & 47261 \\
\hline $\mathrm{NO}_{3}^{-}$ & 0.37 & 0.004 & 0.57 & 0.007 & 53.3 & 924 & 0.42 & 0.013 & 0.48 & 0.015 & 14.9 & 749 \\
\hline \multirow[t]{2}{*}{$\mathrm{SO}_{4}^{2-}$} & 85.70 & 0.987 & 92.62 & 1.066 & 8.1 & 32204 & 31.03 & 0.975 & 32.73 & 1.029 & 5.5 & 20321 \\
\hline & {$\left[\frac{\mathrm{ng}}{\mathrm{s}}\right]$} & {$\left[\frac{\mathrm{ng}}{\mathrm{m}^{2} \mathrm{~s}}\right]$} & {$\left[\frac{\mathrm{ng}}{\mathrm{s}}\right]$} & {$\left[\frac{\mathrm{ng}}{\mathrm{m}^{2} \mathrm{~s}}\right]$} & [\%] & {$\left[\frac{\mathrm{ng}}{\mathrm{md}}\right]$} & {$\left[\frac{\mathrm{ng}}{\mathrm{s}}\right]$} & {$\left[\frac{\mathrm{ng}}{\mathrm{m}^{2} \mathrm{~s}}\right]$} & {$\left[\frac{\mathrm{ng}}{\mathrm{s}}\right]$} & {$\left[\frac{\mathrm{ng}}{\mathrm{m}^{2} \mathrm{~s}}\right]$} & {$[\%]$} & {$\left[\frac{\mathrm{ng}}{\mathrm{md}}\right]$} \\
\hline $\mathrm{CAl}$ & 3.17 & 0.036 & 3.1 & 0.03 & -0 & - & 0.8 & 0.027 & 1.40 & 0.0 & 63.8 & 6528 \\
\hline NON & 17.01 & 0.196 & 8.58 & 0.099 & -49.6 & - & 5.30 & 0.167 & 2.83 & 0.089 & -46.7 & - \\
\hline
\end{tabular}

wells from the concentration-time series. $\mathrm{K}^{+}, \mathrm{Cl}^{-}$and $\mathrm{NO}_{3}^{-}$ show higher $M_{\mathrm{CP}}$ downstream of the Bauerngraben. Due to increased $Q_{\mathrm{CP}}$ at the downstream $\mathrm{CPs}, M_{\mathrm{CP}}$ of $\mathrm{SO}_{4}^{2-}$ are higher downstream even if the concentrations are higher at the upstream CPs. Micropollutant $M_{\mathrm{CP}}$ are lower at the downstream wells for NON whereas $M_{\mathrm{CP}}$ of CAF increase (streamtube 2) or remain unaltered (streamtube 1) at the downstream wells. The major ions $\mathrm{Cl}^{-}$and $\mathrm{SO}_{4}^{2-}$ show the highest $J_{\mathrm{CP}}$ at the test site. Differences of one order of magnitude in $J_{C P}$ between both streamtubes for $\mathrm{NO}_{3}^{-}$indicate a more heterogeneous concentration pattern of $\mathrm{NO}_{3}^{-}$in the groundwater upstream of the test site in comparison to the other wastewater constituents. Higher values of $\Delta M_{\mathrm{CP}}$ in streamtube 2 for the majority of substances can be explained by higher $Q_{\mathrm{ex}}$ from the affected stream section $L_{\mathrm{BG} 2}$. The reasonably conservative ion $\mathrm{SO}_{4}^{2-}$ (reasons for the conservative behavior at the test site are given in the next section) can be used for the estimation of $Q_{\text {ex }}$ by

$Q_{\mathrm{ex}}=\frac{Q_{\mathrm{CP} \text { upstream }}}{L_{\mathrm{BG}}} \times \frac{c_{\text {downstream }}-c_{\text {upstream }}}{c_{\text {surface water }}-c_{\text {downstream }}}$,

with the average concentration in the Bauerngraben $c_{\text {surface water, }}$, at the upstream CP $c_{\text {upstream }}$ and at the down-

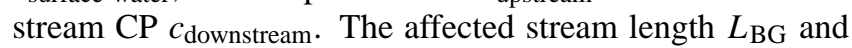
the water flow $Q_{\mathrm{CP}}$ are given in Table 1 . The application of Eq. (2) with the measured data yields $Q_{\text {ex }}$ values of 52 and $104 \mathrm{~L} \mathrm{~m}_{\text {stream }}^{-1} \mathrm{~d}^{-1}$ for streamtube 1 and 2 , respectively.

Therefore less dissolved wastewater constituents infiltrate the groundwater from the Bauerngraben in streamtube 1 . Due to the increased $Q_{\text {ex }}$ to streamtube 2, the $M_{\text {ex }}$ values of $\mathrm{K}^{+}, \mathrm{Cl}^{-}$and CAF (Table 1) are higher in this streamtube than in streamtube $1 . \mathrm{NO}_{3}^{-}$shows an inverse pattern with a higher $M_{\mathrm{ex}}$ in streamtube 1 . The calculated $Q_{\mathrm{ex}}$ from $\mathrm{SO}_{4}^{2-}$ are in the same magnitude of the $Q_{\mathrm{ex}}$ value $\left(85 \mathrm{~L} \mathrm{~m}_{\text {stream }}^{-1} \mathrm{~d}^{-1}\right)$ that was implemented in the groundwater model. A spatially variable $Q_{\mathrm{ex}}$ as a boundary condition for the groundwater model was not assigned because the influence of the stream on the groundwater flow is limited. The streamlines that define streamtubes 1 and 2 (Fig. 1) were only marginally deflected by the stream.

\subsection{Identification of processes that influence concentrations in the groundwater}

The sampled concentrations in the wastewater in February 2008, those in the Bauerngraben from 17 May to 2 June 2008 and from the IPT wells from 28 May to 2 June 2008 are summarized in the boxplot in Fig. 3. The wastewater concentrations were included to show how CSOs from the connected sewer can affect the water composition in the Bauerngraben. The resulting concentrations of wastewater constituents in the Bauerngraben during CSOs may be lower than in the wastewater due to dilution from precipitation and mixing with water from the Bauerngraben, but can still be higher than in the groundwater. Gasperi et al. (2008) compared wastewater concentrations during wet-weather and dry-weather conditions and found out that concentrations during wet-weather conditions are not strictly reduced. The erosion of in-sewer deposits formed within sewer during dry periods was identified as a potential reason for this. However, 

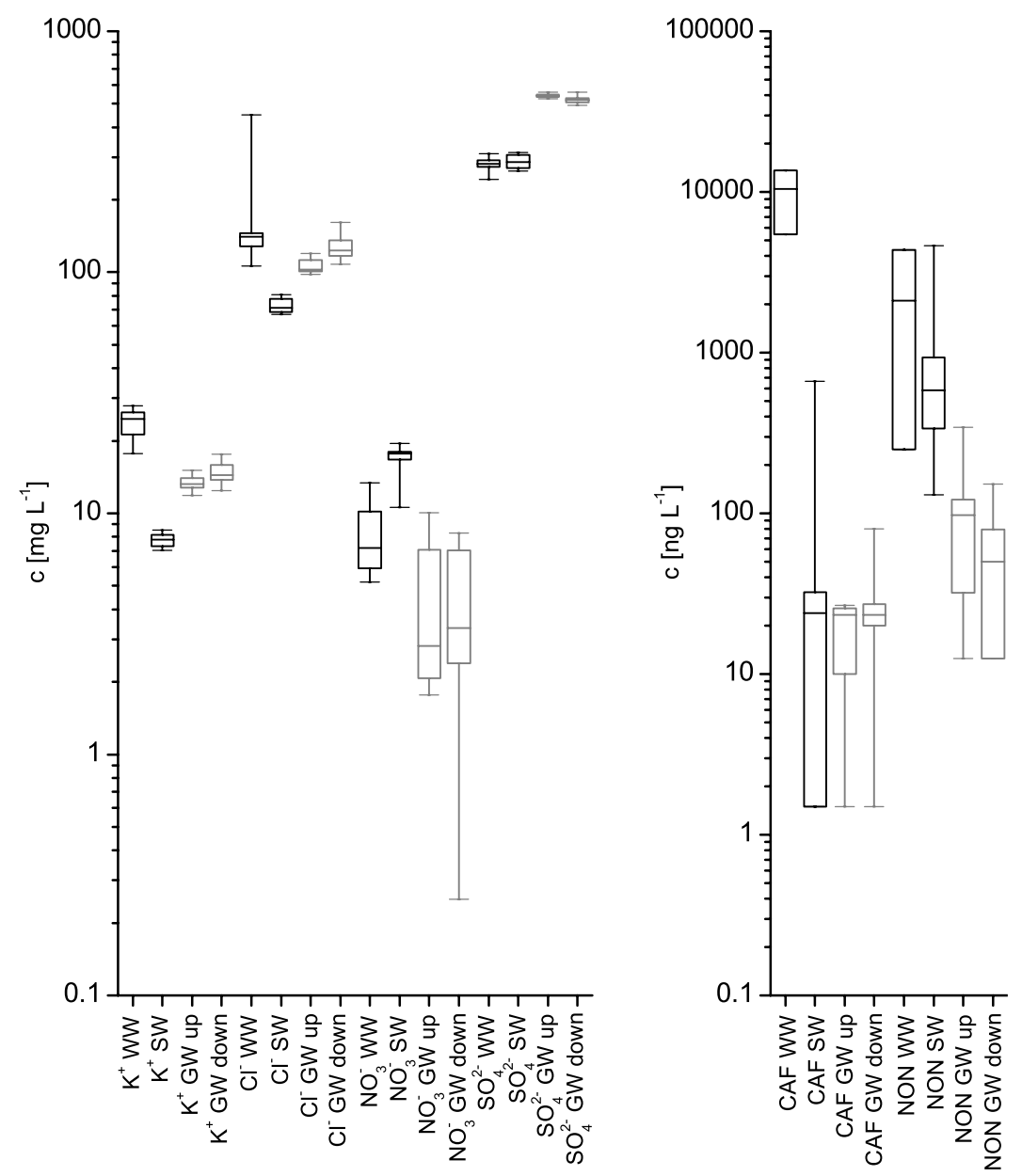

Fig. 3. Boxplot of measured concentrations in the wastewater (WW), surface water (SW) Bauerngraben and groundwater (GW). Black boxplots mark WW and SW. Grey boxplots mark GW. The boxes show the 25 th and 75 th percentile and the median. The whiskers mark the lowest and the highest concentrations. Boxplots of CAF WW and NON WW include no whiskers, because only three values were considered. The lowermost concentration limit for all samples was half of LOD.

measurements in the wastewater during precipitation events were not undertaken to prove this. Thus the shown wastewater concentrations can be helpful to identify CSOs as a cause of temporally high concentrations of the investigated substances in the Bauerngraben. Temporally high concentrations during CSOs are accompanied by high water levels in the Bauerngraben that induce bank storage. In this context Li et al. (2008) defined bank storage as the storage of water in stream banks during the rise of stream level due to a flood. The outflow from the stream banks can also influence the groundwater composition following the CSO event. Concentrations of the three water compartments in Fig. 3 are used to identify processes (a) to (h) that influence the observed $M_{\mathrm{CP}}$ depending on the components' transport properties. In the following section we thus discuss $M_{\mathrm{CP}}, J_{\mathrm{CP}}$ and $M_{\mathrm{ex}}$ substance by substance. Process (f) hydrodynamic dispersion and mixing with groundwater recharge was not included in the detailed discussion because the short flow path of approximately $32 \mathrm{~m}$ between the up- and downstream wells and the floodplain loam cover of the observed aquifer reduce the influence of this process.

\subsection{1 $\mathrm{K}^{+}$}

Higher $M_{\mathrm{CP}}$ downstream of the Bauerngraben point to an exfiltration of $\mathrm{K}^{+}$from the Bauerngraben. Measured concentrations of $\mathrm{K}^{+}$in the Bauerngraben are below concentrations in groundwater. Positive $M_{\mathrm{CP}}$ may partly derive from process (a) temporally high concentrations in the stream. Reversible sorption of $\mathrm{K}^{+}$on streambed materials ((b) retardation in the streambed) and (d) exchange with storage pools in the streambed may lead to an accumulation of $\mathrm{K}^{+}$in the streambed. High $\mathrm{K}^{+}$concentrations in the wastewater indicate that this temporal storage may be supplied by (a). Leaching of the streambed and the stream banks can lead to 
the observed $M_{\mathrm{ex}}$. A reduction of $\mathrm{K}^{+}$via $(\mathrm{g})$ retardation in groundwater is possible, but is likely less important because $\Delta M_{\mathrm{CP}}$ is still positive.

\subsection{2 $\mathrm{Cl}^{-}$}

$\mathrm{Cl}^{-}$behaves conservatively in the groundwater (Barrett et al., 1999), thus processes (b) retardation in the streambed, (c) degradation in the streambed, $(\mathrm{g})$ retardation in groundwater and (h) degradation in groundwater do not occur. Concentrations in the groundwater lie above those in the Bauerngraben, therefore exfiltration from the Bauerngraben must reduce concentrations of $\mathrm{Cl}^{-}$downstream of the Bauerngraben, but the opposite was observed. The calculated $\Delta M_{\mathrm{CP}}$ were positive in both streamtubes. Mayer et al. (1999) reported an accumulation of $\mathrm{Cl}^{-}$in the pore water of benthic sediments of surface waters. Process (d) exchange with storage pools in the streambed can thus be an explanation of the increased $\mathrm{Cl}^{-}$concentrations downstream of the Bauerngraben. Temporally high concentrations of $\mathrm{Cl}^{-}$in the Bauerngraben (a) can originate from CSOs, because concentrations in the wastewater are higher than in the groundwater. Because a high $\Delta M_{\mathrm{CP}}$ (especially in streamtube 2) cannot be explained by exfiltration from the Bauerngraben alone, we thus assume an additional $\mathrm{Cl}^{-}$source in the groundwater or in the streambed that could not be identified with the observed concentrations.

\subsection{3 $\mathrm{NO}_{3}^{-}$}

Figure 3 shows higher $\mathrm{NO}_{3}^{-}$concentrations in the Bauerngraben than in groundwater. Positive $\Delta M_{\mathrm{CP}}$ as a result of (e) mixing of groundwater with exfiltration water seem to be reasonable due to the high mobility of $\mathrm{NO}_{3}^{-}$in groundwater that is not affected by sorption processes (b) retardation in the streambed and $(\mathrm{g}$ ) retardation in groundwater (Freeze and Cherry, 1979). Measured low oxygen concentrations at the test site indicate that denitrification may cause (c) degradation in the streambed and $(\mathrm{h})$ degradation in groundwater. $\mathrm{NO}_{3}^{-}$concentrations in wastewater are considerably low, but will be increased if enough oxygen is available to nitrify dissolved $\mathrm{NH}_{4}^{+}$to $\mathrm{NO}_{3}^{-}$, thus (a) temporally high concentrations in the stream may increase $\mathrm{NO}_{3}^{-}$concentrations in the Bauerngraben. During the wastewater sampling program $\mathrm{NH}_{4}^{+}$concentrations of 41 to $64 \mathrm{mg} \mathrm{L}^{-1}$ were observed, whereas concentrations in the Bauerngraben and groundwater were mostly below $1 \mathrm{mg} \mathrm{L}^{-1}$.

\subsection{4 $\mathrm{SO}_{4}^{2-}$}

We identify (e) mixing of groundwater with exfiltration water as the most important process at the field site which is affecting $\mathrm{SO}_{4}^{2-}$ concentrations. Similar $\mathrm{SO}_{4}^{2-}$ concentrations in wastewater and the Bauerngraben indicate that CSOs will not increase concentrations of $\mathrm{SO}_{4}^{2-}$ in the Bauerngraben. Concentration gradients between the Bauerngraben and groundwater point to a dilution of groundwater with exfiltrating water from the Bauerngraben (e). Anions such as $\mathrm{SO}_{4}^{2-}$ are not affected by sorption thus (b) retardation in the streambed and $(\mathrm{g})$ retardation in groundwater can be excluded for $\mathrm{SO}_{4}^{2-}$. Sulfate reduction ((c) degradation in the streambed and (h) degradation in groundwater) is not relevant because alternative electron donors $\left(\mathrm{O}_{2}\right.$ or $\left.\mathrm{NO}_{3}^{-}\right)$are available at the test site.

\subsubsection{CAF}

A gradient between surface water and groundwater concentrations points to a possible input of CAF into the groundwater via (e) mixing of groundwater with exfiltration water. Higher concentrations in the wastewater than in the Bauerngraben indicate that (a) temporally high concentrations in the stream may occur. Lower limits of CAF concentrations that are below the LOD in surface water and groundwater can be explained by natural elimination processes. Buerge et al. (2003) reported biodegradation as an important elimination process of CAF in surface water. In contrast, sorption was identified to be negligible by the same authors, due to a low octanol-water partition-coefficient $p_{\mathrm{OW}} \approx 0$. Attenuation of organic contaminants in streambeds was reported by Hoehn et al. (2007). Thus we assume that CAF loadings are reduced by (c) degradation in the streambed and (h) degradation in groundwater, but not by (b) retardation in the streambed and $(\mathrm{g})$ retardation in groundwater. The reduction processes lead to a negative $\Delta M_{\mathrm{CP}}$ in streamtube 1. Parts of the CAF input from the Bauerngraben must be degraded in the streambed because the input does not increase $M_{\mathrm{CP} 11}$ above the level of $M_{\mathrm{CP}} 13$. In contrast, streamtube 2 revealed a positive $\Delta M_{C P}$. Assuming similar degradation conditions in the groundwater of both streamtubes, the additional mass flow of CAF in streamtube 2 must originate from the Bauerngraben. Whether this is an effect of reduced degradation in the streambed of streamtube 2 or of the increased $Q_{\text {ex }}$ in streamtube 2 cannot be distinguished with the applied method. An influence of process (d) exchange with storage pools in the streambed may increase or decrease concentrations in the groundwater depending on the degradation rate in the pore water of the streambed.

\subsubsection{NON}

Process (e) mixing of groundwater with exfiltration water may lead to positive $\Delta M_{\mathrm{CP}}$, but observed negative $\Delta M_{\mathrm{CP}}$ in both streamtubes reveal that $\Delta M_{\mathrm{CP}}$ is dominated by (g) retardation in groundwater and $(\mathrm{h})$ degradation in groundwater. Due to the hydrophobic character of NON (Ying et al., 2008), its concentration may be affected by sorption onto streambed sediments. Degradation in streambeds was reported in Bradley et al. (2008). Considering these studies, the outflow concentrations from the Bauerngraben are strongly reduced by (b) retardation in the streambed and 
(c) degradation in the streambed. Therefore (a) temporally high concentrations in the stream and (d) exchange with storage pools in the streambed show only a small influence on the observed $M_{\mathrm{CP}}$. A reliable quantification of degradation and sorption processes in the groundwater and in the streambed using the NON data is not possible. However, the calculated $M_{\mathrm{CP}}$ indicate that NON has only a low mobility in the groundwater at the test site.

\section{Conclusions}

This study shows that the application of integral pumping tests (IPTs) can provide detailed information about the influence of losing streams on the groundwater composition. The operation of IPTs up- and downstream of a wastewater affected target section yields reliable mass flow rates $M_{\mathrm{CP}}$ in groundwater that are not based on conventional point measurements. Exfiltration mass flow rates per stream length unit $M_{\mathrm{ex}}$ from the investigated stream can be estimated for substances that show increased $M_{\mathrm{CP}}$ downstream of the stream. The evaluation of the $M_{\mathrm{CP}}$ was derived for two streamtubes that are defined by two IPT wells per streamtube. The observed four inorganic and two organic wastewater constituents reveal different influences on groundwater quality. Concentrations of major ions $\mathrm{K}^{+}, \mathrm{Cl}^{-}$and $\mathrm{NO}_{3}^{-}$increased, whereas the concentration of $\mathrm{SO}_{4}^{2-}$ was diluted by exfiltration from the stream at the test site. The application of IPT was reasonable, especially for micropollutants, because high variability of concentration-time series during pumping points to high concentration heterogeneity in groundwater. Lower $M_{\mathrm{CP}}$ of technical-nonylphenol (NON) downstream of the target section were primarily caused by elimination processes in groundwater. Similar $M_{\mathrm{CP}}$ patterns were observed for caffeine $(\mathrm{CAF})$ in one streamtube. Higher downstream values of $M_{\mathrm{CP}}$ for CAF in the other streamtube can be a result of stronger exfiltration $Q_{\mathrm{ex}}$ from the stream section in this streamtube or can be due to degradation processes in the streambed. Consequently, $M_{\mathrm{ex}}$ was only given for CAF in one streamtube as well as for $\mathrm{K}^{+}, \mathrm{Cl}^{-}, \mathrm{NO}_{3}^{-}$and $\mathrm{SO}_{4}^{2-}$. The comparison of the concentrations in the groundwater with additional concentration measurements in wastewater and surface water at the test site were used to identify processes that influence the concentrations at the IPT wells downstream. Accordingly, the streambed was recognized as an important storage area, but also as an important area where degradation processes of the wastewater constituents occurs. Wastewater concentrations indicate that combined sewer overflows (CSOs) can induce temporally high concentrations of wastewater constituents in the target stream and thus can influence the groundwater composition at the test site. The results show that losing streams can be a relevant source of inorganic wastewater constituents. For the micropollutants, investigated here, losing streams seem a less important source due to the degradation potential of the streambed.
The proposed IPT method can be operated at other field sites to investigate the influence of small streams on groundwater quality. Due to the significant effort required to carry out an IPT, a complete survey of a stream is impossible. Another limitation is that the method gives only integral $\Delta M$ values, therefore the distinction between different sources (groundwater or surface water) or processes (retardation or degradation) is difficult. Despite these limitations, this study shows that IPTs can be a powerful tool to quantify the influence of losing streams on groundwater quality.

Acknowledgements. The authors thank Gabriele Strenge and Silke Koehler for the laboratory measurements. We acknowledge John Molson (Laval University, Quebec City, Canada) and all colleagues of the Department of Hydrogeology for critical discussions and their help during the IPT field work.

Edited by: P. Grathwohl

\section{References}

Barrett, M. H., Hiscock, K. M., Pedley, S., Lerner, D. N., Tellam, J. H., and French, M. J.: Marker species for identifying urban groundwater recharge sources: A review and case study in Nottingham, UK, Water Res., 33, 3083-3097, 1999.

Bayer-Raich, M.: Integral pumping tests for the characterization of groundwater contamination, Geowissenschaftliche Fakultät, Eberhard-Karls-Universität, Tübingen, Germany, 2004.

Bayer-Raich, M., Jarsjoe, J., Liedl, R., Ptak, T., and Teutsch, G.: Average contaminant concentration and mass flow in aquifers from time-dependent pumping well data: Analytical framework, Water Resour. Res., 40, W08303, doi:10.1029/2004WR003095, 2004.

Bayer-Raich, M., Jarsjoe, J., Liedl, R., Ptak, T., and Teutsch, G.: Integral pumping test analyses of linearly sorbed groundwater contaminants using multiple wells: Inferring mass flows and natural attenuation rates, Water Resour. Res., 42, W08411, doi:10.1029/2005WR004244, 2006.

Bockelmann, A., Zamfirescu, D., Ptak, T., Grathwohl, P., and Teutsch, G.: Quantification of mass fluxes and natural attenuation rates at an industrial site with a limited monitoring network: a case study, J. Contam. Hydrol., 60, 97-121, 2003.

Bradley, P. M., Barber, L. B., Kolpin, D. W., Mcmahon, P. B., and Chapelle, F. H.: Potential for 4-n-nonylphenol biodegradation in stream sediments, Environ. Toxicol. Chem., 27, 260-265, 2008.

Buerge, I. J., Poiger, T., Mueller, M. D., and Buser, H. R.: Caffeine, an anthropogenic marker for wastewater contamination of surface waters, Environ. Sci. Technol., 37, 691-700, 2003.

Choi, B. Y., Yun, S. T., Yu, S. Y., Lee, P. K., Park, S. S., Chae, G. T., and Mayer, B.: Hydrochemistry of urban groundwater in Seoul, South Korea: effects of land-use and pollutant recharge, Environ. Geol., 48, 979-990, 2005.

Eiswirth, M., Wolf, L., and Hoetzl, H.: Balancing the contaminant input into urban water resources, Environ. Geol., 46, 246-256, 2004.

Ellis, J. B.: Pharmaceutical and personal care products (PPCPs) in urban receiving waters, Environ. Pollut., 144, 184-189, 2006. 
Fenz, R., Blaschke, A. P., Clara, M., Kroiss, H., Mascher, D., and Zessner, M.: Quantification of sewer exfiltration using the antiepileptic drug carbamazepine as marker species for wastewater, Water Sci. Technol., 52, 209-217, 2005.

Freeze, R. A. and Cherry, J. A.: Groundwater, Prentice-Hall, Englewood Cliffs, New Jersey, 604 pp., 1979.

Gasperi, J., Garnaud, S., Rocher, V., and Moilleron, R.: Priority pollutants in wastewater and combined sewer overflow, Sci. Total Environ., 407, 263-272, 2008.

Heberer, T.: Occurrence, fate, and removal of pharmaceutical residues in the aquatic environment: a review of recent research data, Toxicol. Lett., 131, 5-17, 2002.

Hoehn, E., Plumlee, M. H., and Reinhard, M.: Natural attenuation potential of downwelling streams for perfluorochemicals and other emerging contaminants, Water Sci. Technol., 56, 59-64, 2007.

Kalbus, E., Schmidt, C., Bayer-Raich, M., Leschik, S., Reinstorf, F., Balcke, G. U., and Schirmer, M.: New methodology to investigate potential contaminant mass fluxes at the stream-aquifer interface by combining integral pumping tests and streambed temperatures, Environ. Pollut., 148, 808-816, 2007.

Leschik, S., Musolff, A., Martienssen, M., Krieg, R., Bayer-Raich, M., Reinstorf, F., Strauch, G., and Schirmer, M.: Investigation of sewer exfiltration using integral pumping tests and wastewater indicators, J. Contam. Hydrol., submitted, 2009.

Li, H. L., Boufadel, M. C., and Weaver, J. W.: Quantifying Bank Storage of Variably Saturated Aquifers, Ground Water, 46, 841850, 2008.

Mayer, T., Snodgrass, W. J., and Morin, D.: Spatial characterization of the occurrence of road salts and their environmental concentrations as chlorides in Canadian surface waters and benthic sediments, Water Qual. Res. J. Can., 34, 545-574, 1999.

Mendoza, J. A., Ulriksen, P., Picado, F., and Dahlin, T.: Aquifer interactions with a polluted mountain river of Nicaragua, Hydrol. Process., 22, 2264-2273, 2008.
Mulliss, R. M., Revitt, D. M., and Shutes, R. B.: The impacts of urban discharges on the hydrology and water quality of an urban watercourse, Sci. Total Environ.t, 190, 385-390, 1996.

Musolff, A., Leschik, S., Reinstorf, F., Strauch, G., Moeder, M., and Schirmer, M.: Xenobiotics in groundwater and surface water of the city of Leipzig, Grundwasser, 12, 217-231, 2007.

Reinstorf, F., Strauch, G., Schirmer, K., Glaeser, H. R., Moeder, M., Wennrich, R., Osenbrueck, K., and Schirmer, M.: Mass fluxes and spatial trends of xenobiotics in the waters of the city of Halle, Germany, Environ. Pollut., 152, 452-460, 2008.

Schirmer, K. and Schirmer, M.: Who is chasing whom? A call for a more integrated approach to reduce the load of micro-pollutants in the environment, Water Sci. Technol., 57, 145-150, 2008.

Schirmer, M., Strauch, G., Schirmer, K., and Reinstorf, F.: Urban hydrogeology - Challenges in research and practice, Grundwasser, 12, 178-188, 2007.

Schwarzenbach, R. P., Escher, B. I., Fenner, K., Hofstetter, T. B., Johnson, C. A., Gunten, U., and Wehrli, B.: The Challenge of Micropollutants in Aquatic Systems, Science, 313, 1005-1184, 2006.

Strauch, G., Moeder, M., Wennrich, R., Osenbrueck, K., Glaeser, H. R., Schladitz, T., Mueller, C., Schirmer, K., Reinstorf, F., and Schirmer, M.: Indicators for assessing anthropogenic impact on urban surface and groundwater, J. Soil. Sediment., 8, 23-33, 2008.

Vazquez-Sune, E., Sanchez-Vila, X., and Carrera, J.: Introductory review of specific factors influencing urban groundwater, an emerging branch of hydrogeology, with reference to Barcelona, Spain, Hydrogeol. J., 13, 522-533, 2005.

Wolf, L., Klinger, J., Hoetzl, H., and Mohrlok, U.: Quantifying mass fluxes from urban drainage systems to the urban soilaquifer system, J. Soil. Sediment., 7, 85-95, 2007.

Ying, G. G., Toze, S., Hanna, J., Yu, X. Y., Dillon, P., and Kookan, R. S.: Decay of endocrine-disrupting chemicals in aerobic and anoxic groundwater, Water Res., 42, 1133-1141, 2008. 